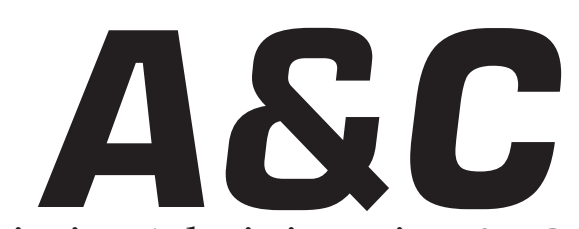

Revista de Direito Administrativo \& Constitucional

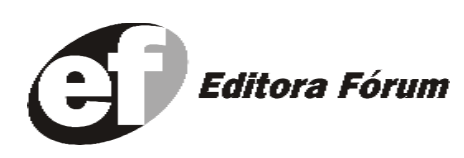

A\&C R. de Dir. Administrativo e Constitucional, Belo Horizonte, ano 4, n.16, p. 1-255, abr.jun. 2004 


\section{A\&C REVISTA DE DIREITO ADMINISTRATIVO E CONSTITUCIONAL}

\section{IPDA}

Instituto Paranaense

de Direito Administrativo

Direção Geral

Romeu Felipe Bacellar Filho

Direção Editorial

Paulo Roberto Ferreira Motta

Direção Executiva

Emerson Gabardo

Conselho de Redação

Edgar Chiuratto Guimarães

Adriana da Costa Ricardo Schier

Célio Heitor Guimarães

Conselho Editorial

\section{Adilson Abreu Dallari Lúcia Valle Figueiredo}

Alice Gonzáles Borges Manoel de Oliveira Franco Sobrinho

Carlos Ari Sundfeld (in memoriam)

Carlos Ayres Britto Marçal Justen Filho

Carlos Delpiazzo Marcelo Figueiredo

Cármen Lúcia Antunes Rocha Márcio Cammarosano

Celso Antônio Bandeira de Mello Maria Cristina Cesar de Oliveira

Clèmerson Merlin Clève Nelson Figueiredo

Clóvis Beznos Odilon Borges Junior

Enrique Silva Cimma Pascual Caiella

Eros Roberto Grau Paulo Eduardo Garrido Modesto

Fabrício Motta Paulo Henrique Blasi

Guilhermo Andrés Muñoz Paulo Neves de Carvalho

Jorge Luís Salomoni Paulo Ricardo Schier

José Carlos Abraão Pedro Paulo de Almeida Dutra

José Eduardo Martins Cardoso Regina Maria Macedo Nery Ferrari

José Luís Said Rogério Gesta Leal

José Mario Serrate Paz Rolando Pantoja Bauzá

Juan Pablo Cajarville Peruffo Sérgio Ferraz

Juarez Freitas Valmir Pontes Filho

Julio Rodolfo Comadira Yara Stropa

Luís Enrique Chase Plate Weida Zancaner

Os conceitos emitidos em trabalhos assinados são de responsabilidade de seus autores, que gozam de inteira liberdade de opinião. e-mail para remessa de artigos, pareceres e contribuições: e.gab.@uol.com.br

ou conselho@editoraforum.com.br Endereço para envio de contribuições: Editora Fórum

Revista A\&C, Av. Afonso Pena, 2770, 15\%16ª andar, Funcionários, CEP 30130-007 - Belo Horizonte - MG

A\&C Revista de Direito Administrativo e Constitucional. Ano 3, n. 11, jan./mar. 2003. Belo Horizonte: Fórum, 2003.

Trimestral

ano 1, n.1, 1999 até ano 2, n.10, 2002 publicada pela Editora Juruá em Curitiba

ISSN: $1516-3210$

1. Direito Administrativo. 2. Direito Constitucional. I. Fórum.

CDD: 342 CDU: 33.342
Editor responsável: Luis Cláudio Rodrigues Ferreira Projeto gráfico: Luis Alberto Pimenta

Diagramação: Anderson Pimenta

Revisora: Olga M. A. Sousa

Pesquisa jurídica: Fátima Ribeiro - OAB/MG 74868 Bibliotecária: Nilcéia Lage de Medeiros -

CRB 1545/MG - 6 a região

(C) Editora Fórum Ltda 2004.

Proibida a reprodução total ou parcial desta obra, por qualquer meio eletrônico, inclusive por processos xerográficos, sem autorização expressa do editor.

Distribuída em todo o território nacional

Assinaturas e comercialização:

Editora Fórum, Av. Afonso Pena, 2770, 15-16 andar, Funcionários, CEP 30130-007 - Belo Horizonte - MG Tel.: (31) 2121-4900 - 0800 704-3737

e-mail: editoraforum@editoraforum.com.br site: www.editoraforum.com.br 


\title{
Sob os Olhos do Grande Irmão: a Luta pela Democracia na Sociedade de Controle $^{1}$
}

\author{
Eneida Desiree Salgado \\ Professora de Direito Eleitoral da Unicenp e da UniBrasil \\ Mestranda em Direito do Estado na UFPR
}

"Não cabe temer ou esperar, mas buscar novas armas"

Gilles Deleuze ${ }^{2}$

Sumário: 1 Introdução: para além do espaço estatal - 2 O espaço da luta democrática - 3 A virada de Foucault: poder disciplinar e biopoder - 4 A sociedade de controle e o novo espaço de luta - 5 Conclusão: a busca de novas armas - Referência

\section{Introdução: para além do espaço estatal}

Todas as sociedades e Estados ocidentais se declaram democráticos. Com a inclusão em suas constituições dos direitos fundamentais e do princípio da soberania popular, parecem ter esgotado o problema da liberdade e da igualdade.

O desenvolvimento das teorias democráticas não escapa desta visão. O poder soberano sempre é o centro das preocupações, ainda que elas se desloquem para a relativização do poder estatal provocada pela globalização.

Mas o poder não está somente no Estado.

Bobbio vê a democracia como o poder em público. ${ }^{3} \mathrm{O}$ poder soberano, depois de conquistas históricas, é, ao menos geralmente, exercido em público. Sua atuação pode dar-se apenas por lei (publicada e publicamente votada). Há (ou deveria haver) transparência na atuação do Poder Executivo, e os julgamentos são, em regra, públicos.

As demais formas de poder, disseminadas na sociedade, não são poderes em público. São poderes mascarados, ocultos e ao mesmo tempo

Texto e l a borado pela mestranda Ene ida Desiree Salgado, sob a orientação do Prof. Dr. Ricardo Marcelo

Fonseca, no Núcleo História, Direito e Subjetividade, do Programa de Pós-Graduação em Direito da Univesidade Federal do Paraná.

2 Post-scriptum sobre as Sociedades de Controle. In: Conversações, p. 220

${ }^{3}$ Bobbio escolhe esta definição de democracia, para "indicar todos aqueles expedientes institucionais que obrigam os governantes a tomarem as suas decisões às caras e permitem que os governados 'vejam' como 
profundamente atuantes. O indivíduo está sujeito também a estes poderes e sua liberdade não pode ser celebrada aos quatro ventos enquanto submissa à disciplina, à regulamentação e ao controle.

O estudo aqui desenvolvido propõe o reconhecimento da existência destas outras esferas de poder e a busca por espaços de luta e de resistência a estas distintas formas de dominação.

A democracia não se realiza apenas com a limitação do poder do Estado. A liberdade e a igualdade exigem todas as libertações.

\section{O espaço da luta democrática}

Os teóricos, quase todos, discutem o conceito e a validade da democracia, assim como o modo de seu exercício, dentro do contexto do Estado. O único poder levado em consideração é o poder soberano, que permite ser limitado e controlado por leis e institutos jurídicos.

Neste contexto, o Direito (ao menos em teoria) permite a concretização da democracia, desde que efetivo, tornado real. As relações de poder, juridicizadas, são estremadas pelos direitos fundamentais de forma a permitir a realização simultânea dos princípios da igualdade e da liberdade.

Os questionamentos sobre os limites da democracia na sociedade atual residem, principalmente, nos efeitos do fenômeno da globalização. ${ }^{4}$ Aí se acumulam argumentos contrários à sua possibilidade face à destruição da soberania do Estado-nação, da existência de centros de decisão supranacionais. Evidencia-se a preocupação com o modelo de poder soberano, como exercido pelo Estado, ainda que nas mãos de estruturas que lhe escapem das fronteiras.

Como resposta a este problema, sempre sem fugir do modelo soberano de poder, autores defendem uma federação mundial (com um Parlamento representativo) ou uma democracia cosmopolita. Assim Habermas traz a possibilidade de criação de um Estado federativo pós-nacional, baseado em uma cidadania cosmopolita, que permita a

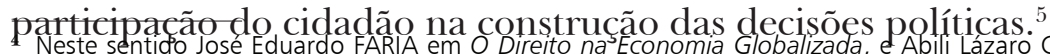

Neste sentido Jose Eduardo FARIA em Direito naÉconomia Globalizada, e Abili Lazaro Castro de LIMA, Globalização Econômica, Política e Direito.

${ }^{5}$ Principalmente em A constelação pós-nacional. Mas Habermas é crítico em relação a esta sugestão, principal mente face aos perigos do deslocamento do poder: "na transição de uma ordem marcada pelo Estado nacional para uma cosmopolita não se sabe exatamente o que é mais perigoso: o mundo (que naufraga) dos sujeitos soberanos do direito internacional que perderam há tempos a sua inocência ou a situação misturada confusa de instituições e de conferências supranacionais que podem atribuir legitimações questionáveis, mas que ainda continuam dependentes da boa vontade dos Estados poderosos e das alianças. Nessa situação lábil é verdade que os direitos humanos oferecem o único fundamento de legitimação dentre todos os reconhecidos para a política da comunidade dos povos; quase todos os Estados adotaram o teor da carta dos direitos humanos da ONU (entrementes aperfeiçoada)". Esta citação encontra-se nas páginas 150 e 151 da obra citada.

A \& C R. de Dir. Administrativo e Constitucional, Belo Horizonte, ano 4, n. 16, p. 11-28, abr./jun. 2004 
Embora seja um enfoque importante, pois enfrenta um problema real, não esgota a luta pela liberdade e pela democracia. As relações de poder, que impedem a realização dos princípios da igualdade e da liberdade, têm lugar também fora do espaço estatal.

Gramsci dá uma pista. ${ }^{6}$ Sua teoria sobre os aparelhos privados de hegemonia apresenta a sociedade civil como lugar de relações do poder. ${ }^{7}$ Vê nestes aparelhos espaços de participação política, que precisam ser conquistados para que se possa alterar a configuração do poder estatal. Assim, não basta analisar o poder soberano, o poder emanado do Estado.

A luta, em Gramsci, começa antes. A guerra de posição é sua estratégia para que a necessária divisão entre governantes e governadores (irredutível em certas condições reais) dê-se de forma a respeitar a vontade coletiva. Para isto, é necessário desenvolver o conceito de hegemonia.

A hegemonia se opõe à autoridade, implica consenso, e tem supremacia face à força da sociedade política. É o predomínio ideológico dos valores e normas burguesas sobre as classes subalternas e a aceitação por parte dos dominados de uma concepção de mundo que pertence aos seus dominadores. O Estado, em Gramsci, é sociedade civil mais sociedade política, é hegemonia garantida pela coerção.

Com o conceito ampliado de Estado, a luta contra o poder opressor ocorre, assim, em duas frentes: contra a autoridade, mas, principalmente, na conquista de espaços de hegemonia da sociedade civil, com a formação de consensos em torno de valores diferentes daqueles da classe dominante. A teoria de Gramsci sinaliza a necessidade de expandir a luta democrática.

Carlos Nelson Coutinho liga a idéia gramsciana de democracia a Palmiro Togliatti e Eugenio Curiel e seu conceito de democracia progressiva: "um regime democrático republicano que, graças à articulação dialética entre os organismos tradicionais de representação democrática (parlamentos, etc.) e os novos institutos de democracia direta (conselhos de fábrica, de bairro, etc.), permite o avanço progressivo no sentido de transformações sociais e econômicas profundas, da conquista permanente de posições no rumo do socialismo". ${ }^{8}$

\footnotetext{
${ }^{6}$ Os argumentos de Gramsci podem ser verificados, principalmente, em Pensare la Democrazia e Maquiavel, Política e o Estado Moderno; na obra de Carlos Nelson Coutinho, Gramsci, em O Conceito de Hegemonia em Gramsci de Luciano Gruppi e ainda em Estado e Teoria Política de Martin Carnoy.

${ }^{7}$ Embora sua teoria ampliada do Estado coloque a sociedade civil dentro da esfera estatal, Gramsci mostra outro espaço de luta pela democracia.

${ }^{8}$ COUTINHO, Gramsci, p. 161.
}

A \& C R. de Dir. Administrativo e Constitucional, Belo Horizonte, ano 4, n. 16, p. 11-28, abr./jun. 2004 
E a teoria de Gramsci, na busca da democracia, se impõe como uma prática. Ao tratar das necessárias análises das relações de força, afirma que estas análises não podem ser um fim em si mesmas, mas revestem-se de significado somente para se justificar uma atividade prática. "Elas mostram quais são os pontos de menor resistência, onde a força da vontade pode ser aplicada mais utilmente, sugerem as operações táticas imediatas, indicam como se pode melhor estabelecer uma campanha de agitação política, qual linguagem será melhor compreendida pelas multidões, etc. $\mathrm{O}$ elemento decisivo de cada situação é a força permanentemente organizada e predisposta que se possa fazer avançar quando se avalia que uma situação é favorável (e é favorável somente enquanto uma tal força exista e seja plena de ardor combativo); por isso a tarefa essencial é aquela de se dedicar sistematicamente e pacientemente a formar, desenvolver, deixar sempre mais homogênea, compacta, consciente de si mesma aquela força". ${ }^{9}$

Chantal Mouffe propõe um projeto de uma política democrática radical, partindo da teoria gramsciana da hegemonia. Suas colocações evidenciam a necessidade de uma construção não-racionalista da teoria política e da imperatividade de se experimentar o novo. ${ }^{10}$

Seu projeto de democracia radical se propõe a "defender a democracia e expandir a sua esfera de aplicabilidade a novas relações sociais, tendo como objetivo criar um outro tipo de articulação entre os elementos da tradição democrática liberal, já não enquadrando os direitos numa perspectiva individualista, mas concebendo-os como 'direitos democráticos'. Será assim, criada uma nova hegemonia, que será o resultado da articulação do maior número possível de lutas democráticas". E continua: "Aquilo que necessitamos é de uma hegemonia de valores democráticos, o que exige uma multiplicação de práticas democráticas, institucionalizando-as num número cada vez mais diverso de relações sociais, de forma que possa ser constituída uma multiplicidade de posições de sujeito a partir de uma matriz democrática". ${ }^{11}$

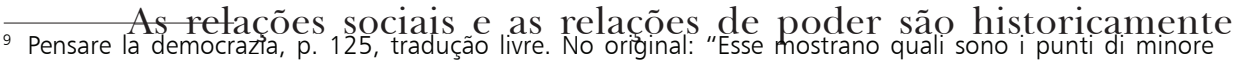
resistenza, dove la forza della volontà può essere applicata piú fruttuosamente, suggeriscono le operazioni tattiche immediate, indicano como si può meglio impostare una campagna di agitazione politica, quale linguaggio sarà meglio compreso dalle moltitudini ecc. L'elemento decisivo di ogni situazione è la forza permanentemente organizzata e predisposta di lunga mano che si può fare avanzare quando si giudica che una situazione è favorevole (ed è favorevole solo in quanto una tale forza esista e sia piena di ardore combattivo); perciò il compito essenziale è quello di attendere sistematicamente e pazientemente a formare, sviluppare, rendere sempre piú omogenea, compatta, consapevole di se stessa questa forza".

${ }^{10}$ Os argumentos de Chantal Mouffe aqui apresentados estão principalmente em sua obra O Regresso do Político, no artigo Politics and Passions - the stakes of democracy e em uma palestra proferida na Universida de Federal de Santa Catarina em 11 de abril de 2003.

${ }^{11}$ MOUFFE. O Regresso do Político, p. 33.
}

A \& C R. de Dir. Administrativo e Constitucional, Belo Horizonte, ano 4, n. 16, p. 11-28, abr./jun. 2004 
construídas por uma contingência hegemônica — não é algo natural, que deva ser respeitado ou entendido como a única alternativa. Assim é possível ir além do que está aí.

O resgate do político ocorre pelo estabelecimento de novas instituições para dar espaço ao pluralismo - esta é sua idéia de democracia radical. Para a realização do princípio da igualdade e da liberdade é necessário escapar do espaço político hoje delimitado e democratizar todas as relações sociais sob aqueles princípios.

A democracia radical, como projeto da esquerda, deve construir uma hegemonia alternativa à globalização neoliberal. Deve estender o espaço público, para ser capaz de dar conta da complexidade das sociedades atuais. Novas formas de participação política, de exercício da soberania popular, devem ser implantadas, para além do parlamento e do espaço estatal. É necessário um espaço de negociação de conflitos, de realização do pluralismo. Os movimentos sociais devem ser levados em conta, todos eles, pois há equivalência das lutas democráticas.

Quando Mouffe exige o exercício da democracia em outros espaços além da esfera estatal, a democratização de todas as relações sociais baseada nos princípios da igualdade e da liberdade, mostra que a luta pela democracia no espaço estatal é insuficiente. Há outras esferas em que deve ser travada para que uma sociedade seja considerada democrática.

Boaventura de Sousa Santos propõe reinventar a democracia, através da construção de um novo contrato social, conflitual e inclusivo. ${ }^{12}$ A nova democracia, redistributiva, exige uma repolitização do Estado, com a admissão de concepções alternativas do bem comum.

Para que isto seja possível, Boaventura concentra-se na busca de sociabilidades alternativas que abram espaço para possibilidades democráticas. Parte-se da exigência de reinvenção de um espaço-tempo onde seja favorecida a deliberação democrática. Três princípios devem ser observados nesta reinvenção: um pensamento alternativo de alternativas, que fuja do conformismo realista; baseado em uma ação turbulenta de um pensamento em turbulência, que permita o fortalecimento dos excluídos com a incorporação de sua ansiedade pelos incluídos; e o afastamento do fascismo societal que trivializa e restringe os espaços de deliberação democrática. ${ }^{13}$

Esta exigência cosmopolita implica na construção do novo contrato

\footnotetext{
12 In: Reinventar a Democracia: entre o pré-contratualismo e o pós-contratualismo.

${ }^{13} \mathrm{O}$ desenvolvimento destes princípios se encontra nas páginas 109 a 112 do texto.
}

A \& C R. de Dir. Administrativo e Constitucional, Belo Horizonte, ano 4, n. 16, p. 11-28, abr.jun. 2004 
social, que inclua os espaços-tempos local, regional e global, sem se apegar às distinções entre Estado e sociedade civil.

Como propostas práticas (e mais uma vez a teoria servindo para mudar a realidade) são apresentadas a redescoberta democrática do trabalho e o Estado como novíssimo movimento social. Aquela demanda a realização de quatro condições: a partilha democrática do trabalho, o reconhecimento do polimorfismo do trabalho, a separação entre trabalho produtivo e economia real por um lado e capitalismo financeiro ou economia de cassino por outro e a reinvenção do movimento sindical.

O Estado como novíssimo movimento social é apresentado como um Estado experimental. Frente à nova organização política, o Estado apresentase como "uma relação política parcelar e fraturada, aberta à competição entre agentes de subcontratação política, com concepções alternativas de bem comum e de bens públicos. Neste novo marco, o Estado, mais que uma materialidade institucional e burocrática, é um campo de luta política muito menos codificada e regulada que a luta política convencional. É neste novo marco que as várias formas de fascismo societal buscam articulações que amplificam e consolidam as suas regulações despóticas, transformando assim o Estado em componente do seu espaço privado. E será também neste marco que as forças democráticas terão de centrar as suas lutas por uma democracia redistributiva, transformando o Estado em componente do espaço público não estatal. É esta última transformação do Estado que eu designo por Estado, novíssimo movimento social”. ${ }^{14}$

A democratização, também em Boaventura, deve atingir o Estado e a esfera não estatal, pois "não faz sentido democratizar o Estado se simultaneamente não se democratizar a esfera não estatal. Só a convergência dos dois processos de democratização garante a reconstituição do espaço público de deliberação democrática". ${ }^{15}$

$\mathrm{Na}$ sociedade atual, é visível que as relações de poder estão em todos os lugares. A virada de Foucault desmascara o poder disciplinar e o biopoder — não há mais como ficar cego às demais formas de submissão. Liberdade política garantida constitucionalmente por um Estado de Direito não é liberdade de fato. É uma ficção jurídica, uma canção retórica sem significado. O Direito, sozinho, não pode emancipar o sujeito. As amarras do sujeito estão muito além do Direito e do Estado.

\section{A virada de Foucault: poder disciplinar e biopoder}

Opoder, conforme visto por Foucault, exerce-se entre um direito ${ }^{14}$ BOAVENTURA. Reinventar a Democracia, p. 121 .

${ }^{15}$ Id., p. 122

A \& C R. de Dir. Administrativo e Constitucional, Belo Horizonte, ano 4, n. 16, p. 11-28, abr.jun. 2004 
público de soberania e uma mecânica polimorfa da disciplina. O autor não trabalha com o conceito clássico de poder, como um direito do qual se seria possuidor como de um bem, passível de transferência ou alienação mediante um ato jurídico ou ato fundador do direito. Estuda os mecanismos do poder, as regras do direito e os efeitos da verdade para possibilitar uma investigação de todo o fenômeno de dominação.

O poder político tem como função reinserir perpetuamente a força repressora mediante uma espécie de guerra silenciosa, nas instituições, nas desigualdades econômicas, na linguagem e nos corpos. A soberania é o resultado de uma operação jurídica da ordem da troca contratual. Sua teoria foi uma arma da luta política e teórica nos séculos XVI e XVII, mas limitase a um tríplice primitivismo: sujeito, unidade do poder e lei. E consiste no problema central do Direito: a dissolução do fato da dominação, mascarar os direitos legítimos da soberania e a obrigação legal da obediência. A soberania não esgota, no entanto, o exercício do poder.

Há dois sistemas de análise do poder. Um deles refere-se ao contrato, à opressão e ao binário legítimo e ilegítimo. O outro à guerra, à repressão, ao binário luta e submissão. É este segundo sistema o objeto sobre o qual se debruçam as análises foucaultianas.

Foucault analisa o poder para além do espaço estatal, além do poder soberano. Toma a dominação como tema central, e o exercício do poder através das técnicas disciplinares e do biopoder. Sua análise do poder é concreta, quer determinar quais são os dispositivos do poder, em seus efeitos, em seus mecanismos, em suas relações, que se exercem em diferentes níveis da sociedade, em campos e com extensões variadas.

O poder exerce-se capilarmente, em todas as relações sociais. É microfisicamente difundido em diversas formas. Este poder é circular e transita entre os indivíduos, não tem um lugar, um centro. A relação assimétrica entre os indivíduos revela um poder micro, uma relação de sujeição, de dominador e dominado.

A norma é o instrumento deste poder não-soberano. É um parâmetro, uma medida para individualizar vinculada por uma determinada forma de poder. São duas as formas, que podem agir de forma sobreposta, de poder normalizador: o poder disciplinar e o biopoder.

O poder disciplinar é tratado por Foucault na terceira parte de Vigiar e Punir. ${ }^{16}$ No século XVIII o poder sobre o corpo passa a ser exercido como 
um controle constante, assemelhado a uma manutenção mecânica, cuja coerção é ininterrupta. O poder de fabricar soldados faz do corpo o seu alvo.

As disciplinas são "métodos que permitem o controle minucioso das operações do corpo, que realizam a sujeição constante de suas forças e lhes impõem uma relação de docilidade-utilidade" ${ }^{17}$ Estes métodos se tornam as fórmulas gerais de dominação, produzindo relações que combinam, maximizando, utilidade e obediência.

O poder disciplinar é o poder de adestrar, de fabricar indivíduos, de reduzir suas diferenças a um modelo adequado. Um poder que desarticula e recompõe o corpo, corpo submisso e exercitado. Ao mesmo tempo em que aumenta sua força econômica, diminui sua força política. Funciona como elo entre o aumento da aptidão e da dominação.

Este poder se manifesta por uma multiplicidade de processos, de origens diversas e localização dispersa, que funcionam articuladamente em diferentes campos de aplicação e formam o esboço de um método geral. Não quer substituir o poder soberano, mas acaba por influenciar seus mecanismos e impor-se a seus processos.

Os recursos para o bom adestramento são a vigilância hierárquica, a sanção normalizadora e o exame. A vigilância hierárquica representa um poder múltiplo, automático e autônomo, que constrange o sujeito em todas as suas relações. É um dispositivo que obriga a um jogo do olhar, onde não é possível ver o observador, mas o observado sabe-se vigiado todo o tempo. A arquitetura passa a permitir um controle interior, detalhado e a vigilância passa a integrar o aparelho de produção. A vigilância é uma máquina silenciosa, que funciona sem cessar.

A sanção normalizadora está abaixo da sanção estritamente jurídica, e apresenta-se como um pequeno mecanismo penal. O poder disciplinar possui suas leis próprias, suas formas particulares de sanção e suas instâncias de julgamento. Sua micropenalidade se relaciona ao tempo, à atividade, à maneira de ser, aos discursos, ao corpo, à sexualidade e se efetiva por uma série de processos sutis onde cada indivíduo fica preso em uma universalidade punível-punidora. A sanção disciplinar é corretiva e promove o exercício. Estabelece penas e prêmios em todos os âmbitos e assim hierarquiza bons e maus indivíduos. Compara, diferencia, hierarquiza, homogeniza, exclui - ou seja: normaliza.

${ }^{16}$ FOUCAULT, Michel. Vigiar e Punir, p. 125-199.

${ }^{17}$ Id., p. 126

A \& C R. de Dir. Administrativo e Constitucional, Belo Horizonte, ano 4, n. 16, p. 11-28, abr./jun. 2004 
O poder da Norma surge das disciplinas e une-se aos poderes da Lei, da Palavra e do Texto, da Tradição. A regulamentação é, com a vigilância, o instrumento de poder na modernidade. Neste ponto, Foucault faz um apontamento relevante ao problema da democracia, ao afirmar que "compreende-se que o poder da norma funcione facilmente dentro de um sistema de igualdade formal, pois dentro de uma homogeneidade que é a regra, ele introduz, como um imperativo útil e resultado de uma medida, toda a gradação das diferenças individuais". ${ }^{18}$

O exame materializa um controle normalizante, ritualizado - exercese como uma cerimônia do poder, para demonstrar força e estabelecer verdades. É uma técnica que torna o poder invisível e constitui o indivíduo como efeito e objeto do saber, o sujeita e o objetiva. Combina os dois recursos anteriores. Ele inverte a economia da visibilidade no exercício do poder, fazendo desaparecer o detentor do poder e iluminando seu objeto - poder ser visto sempre mantém o indivíduo disciplinado. O exercício do poder se dá em todos os níveis, chegando a configurar uma era de exame interminável, de objetivação limitadora. O exame permite a documentação das individualidades, sua descrição e classificação - que possibilitarão, posteriormente, o desenvolvimento de um controle sobre a população. ${ }^{19} \mathrm{O}$ exame faz de cada indivíduo um caso.

O poder, no regime disciplinar, é cada vez mais anônimo e mais funcional. Os mecanismos científico-disciplinares permitem qualificar, classificar, controlar e punir os sujeitos, sem que haja um centro de poder, um lugar para o seu exercício. As disciplinas tomam o poder através de discursos médicos, penitenciários, pedagógicos. Os corpos são assim continuamente ocupados pelo poder para tornarem-se úteis.

O panóptico é a arquitetura do poder disciplinar. O controlador que tudo vê e que não é visto. O poder é invisível, e, desta forma, impossível de ser controlado, inverificável. O panótico automatiza e desindividualiza o poder.

Age de forma a separar as individualidades, induzindo o indivíduo a saber-se permanentemente visível. Assim, o poder funciona de maneira

\footnotetext{
${ }^{18}$ Id., p. 164.

${ }^{19}$ Neste ponto, Foucault faz referência ao nascimento das ciências humanas, que "deve ser procurado nesses arquivos de pouca glória onde foi elaborado o jogo moderno das coerções sobre os corpos, os gestos, os comportamentos". E: "o poder produz; ele produz realidade; produz campos de objetos e rituais da verdade. O indivíduo e o conhecimento que dele se pode ter se originam nessa produção". E ainda afirma que as ciências humanas, "com que nossa 'humanidade' se encanta há mais de um século têm sua matriz técnica na minúcia tateante e maldosa das disciplinas e das suas investigações". Vigiar e Punir, p. 170, 172 e 198.
}

A \& C R. de Dir. Administrativo e Constitucional, Belo Horizonte, ano 4, n. 16, p. 11-28, abr./jun. 2004 
automática, sem depender de quem o exerce. O panóptico fabrica efeitos homogêneos de poder, é um laboratório do poder. É idealmente a tecnologia política perfeita, pois ao mesmo tempo em que reduz o número dos que exercem o poder, aumenta o seu alcance.

O dispositivo do panóptico pode ser democraticamente controlado, como o exercício do poder em um edifício transparente, passível de ser fiscalizado por toda a sociedade.

As técnicas disciplinares permitem uma forma contínua e não violenta do exercício do poder. Funcionando de maneira difusa e polivalente, elas atravessam e penetram toda a sociedade. Qualquer instituição pode se apropriar do modelo disciplinar e atuar com seus instrumentos. Este poder se generaliza na sociedade moderna, tornando-a uma sociedade disciplinar, uma sociedade da vigilância.

A disciplina pode ser vista como a disciplina-bloco, das instituições fechadas, e como a disciplina-mecanismo, conforme o panoptismo. Com a extensão das instituições disciplinares, invertem-se funcionalmente as disciplinas, os mecanismos disciplinares se ramificam e circulam em estado "livre", e há a estatização destes mecanismos, através da polícia do poder soberano com sua vigilância absoluta e onipresente.

Foucault afirma que a disciplina não é uma instituição, mas um tipo de poder, uma modalidade de seu exercício, uma tecnologia que pode ser aplicada em diversos setores, com um específico conjunto de instrumentos, de técnicas, de procedimentos, de níveis de aplicação e de alvos. ${ }^{20}$

A sociedade disciplinar se forma com a disseminação do poder disciplinar nas outras modalidades de poder, que permite uma atuação infinitesimal do poder, em todas as relações. A sociedade atual não é de espetáculo, mas da vigilância. ${ }^{21}$ Não se vê, se é visto.

Processos históricos, econômicos, jurídico-políticos e científicos favorecem o surgimento da sociedade disciplinar, com sua demanda pelo exercício menos custoso possível do poder, econômica e politicamente. O poder deve ser discreto, não flagrantemente violento. O desenvolvimento econômico capitalista não permite mais os rasgos autoritários do poder soberano, mas dá espaço à sujeição. Com a burguesia no poder, a demanda de igualdade política é levada ao poder soberano e impõe o reconhecimento

\footnotetext{
20 Id., p. 189

${ }^{21}$ Será que os espetáculos televisivos de realidade (ou assim chamados) não servem exatamente para mascarar a vigilância, colocando os indivíduos em um falso lugar de observador para fazê-los esquecer ao menos por um momento que estão sendo totalmente vigiados?
} 
de direitos individuais - em contrapartida, o poder assimétrico das disciplinas atua em todas as relações sociais, falseando aquela liberdade.

As disciplinas surgem, assim, como um contradireito, como um avesso do contrato, onde reina a desigualdade e a assimetria. Pois, "enquanto os sistemas jurídicos qualificam os sujeitos de direito, segundo normas universais, as disciplinas caracterizam, classificam, especializam; distribuem ao longo de uma escala, repartem em torno de uma norma, hierarquizam os indivíduos em relação uns aos outros, e, levando ao limite, desqualificam e invalidam”. ${ }^{22}$ Trabalham como contrapeso das normas jurídicas de distribuição do poder — instrumentos de uma contra-democracia.

Ajustiça e o direito são invadidos por este contradireito, agora conteúdo efetivo e institucionalizado da lei.

Outra forma de atuação do poder normalizador é o biopoder. Foucault trata do biopoder principalmente no quinto capítulo da História da Sexualidade I: A vontade de saber ${ }^{23}$ e na aula de 17 de março de 1976 do curso Em defesa da sociedade.

Enquanto o poder disciplinar atua sobre os corpos, sobre os indivíduos, o biopoder atua sobre as populações. A disciplina atua mediante o treinamento individual, o biopoder busca o equilíbrio global. Ao poder disciplinar correspondem corpo / organismo / disciplina / instituições; ao biopoder população / processos biológicos / mecanismos regulamentadores / Estado. ${ }^{24}$ A localização destes poderes em instituições e no Estado não é necessária. Os poderes sobre o corpo excedem estes espaços.

São mecanismos, técnicas e tecnologias do poder que surgem a partir da segunda metade do século XVIII, com o aparecimento das cidades e a preocupação com a espécie, com o advento de problemas científicos e políticos relacionados com a população (natalidade, longevidade, saúde pública, habitação e migração). Impõe a preocupação com a assistência e com a seguridade, como mecanismos racionais de otimização da força de trabalho. O biopoder é necessário ao desenvolvimento do capitalismo, que passa a demandar uma inserção controlada dos corpos na produção e a adequação dos fenômenos populacionais aos processos econômicos.

O aparecimento deste novo poder sobre os corpos, no entanto, só é possível graças à atuação das técnicas disciplinares. O biopoder modifica

\footnotetext{
22 Vigiar e Punir, p. 195.

${ }^{23}$ E sexualidade porque é nela que se unem o biopoder e o poder disciplinar, combinam-se as técnicas disciplinares e os procedimentos reguladores. Sobre ela manifestam-se conjuntamente as duas formas de poder sobre a vida: a anátomo-política do corpo e a biopolítica da população.

${ }^{24}$ FOUCAULT, Michael. Em Defesa da Sociedade, p. 298.
}

A \& C R. de Dir. Administrativo e Constitucional, Belo Horizonte, ano 4, n. 16, p. 11-28, abr./jun. 2004 
parcialmente o poder disciplinar e impõe novas tecnologias, instrumentos diferentes. Ambos se exercem simultaneamente. A dinâmica da cidade revela o funcionamento conjunto destas duas formas de poder, com a manifestação de mecanismos disciplinares e reguladores. O biopoder se contrapõe ao poder soberano (enquanto este faz morrer e deixa viver, aquele deixa morrer e faz viver) mas não o elimina. Há uma mudança nos mecanismos de poder: o poder de morte, característica do poder-confisco, dá lugar a um poder que assume a função de gerir a vida. As guerras deixam de ser pelo interesse do soberano e passam a justificar-se pelo interesse da população, por sua sobrevivência — uma questão biológica.

Surge um novo elemento, ainda não considerado pela teoria do direito: a população, um corpo múltiplo que não se confunde com a sociedade. Disso decorre a normatização da vida, do homem-espécie. O biológico é estatizado. A vida entra no campo das técnicas políticas - é controlada pelo saber e pelo poder. Este poder atua para regular, otimizar um estado de vida, construir um equilíbrio global através de previsões e estatísticas.

A lei revela-se insuficiente para regular as relações sociais e é tomada pela norma. A profusão de leis apenas disfarça um poder fundamentalmente normalizador. A vida passa a ser o objeto da lei e também das lutas políticas, que exigem o reconhecimento do direito à vida, ao corpo, à saúde.

Foucault vislumbra a sociedade da normalização, "efeito histórico de uma tecnologia de poder centrada na vida”, ${ }^{25}$ que não é caracterizada pela difusão absoluta das técnicas disciplinares - é onde se combinam a disciplina e a regulamentação. A norma faz atuar o poder disciplinar e o biopoder, disciplina e regulamenta, aplica-se aos corpos e às populações.

O biopoder autoriza o nascimento do racismo de Estado. A incorporação da biopolítica pelo poder soberano permite que este decida quem deve viver e quem deve morrer, utilizando seu poder de morte com fundamentos biológicos e justificados por um interesse da população. "A raça, o racismo, é a condição de aceitabilidade de tirar a vida numa sociedade de normalização". ${ }^{26}$ Aqui se evidencia a ligação entre o discurso do poder e os saberes biológicos.

A virada foucaultiana evidencia que o problema do poder está além das fronteiras do Estado. A dominação e a sujeição não se limitam à relação

${ }^{25}$ FOUCAULT, Michael. História da Sexualidade I: A vontade de saber, p. 135.

${ }^{26}$ FOUCAULT. Em Defesa da Sociedade, p. 306.

A \& C R. de Dir. Administrativo e Constitucional, Belo Horizonte, ano 4, n. 16, p. 11-28, abr.jun. 2004 
soberano-súdito, mas estão presente em todas as relações sociais. A opressão não se dá apenas face à lei, mas por mecanismos diversos, tecnologias diferentes que submetem os corpos e as populações. Ainda que o Estado possa se apropriar destas novas formas de poder, a luta não pode se resumir a um combate à dominação estatal. A liberdade e a democracia exigem outras frentes de batalha.

\section{A sociedade de controle e o novo espaço de luta}

A sociedade atual é uma sociedade de controle, onde nada escapa à observação e à normalização. As técnicas de poder se espalham pelas relações sociais e nada do que o indivíduo faz escapa de uma documentação (por vezes virtual) que é partilhada entre diversas instituições.

Gilles Deleuze trata das sociedades de "controle", ${ }^{27}$ afirmando que elas escapam do conceito das sociedades disciplinares. Enquanto estas exercem seu poder principalmente através do confinamento, de instituições, a sociedade de controle funciona com o controle contínuo e com a comunicação instantânea.

A sociedade de controle utiliza novos tipos de instrumentos e de sanções. As instituições se tornam cada vez mais abertas e intercambiantes, produzindo uma formação (e um controle dela derivado) permanente e incessante. As máquinas da sociedade de controle são os computadores, como foram as máquinas simples ou dinâmicas para a sociedade de soberania e as máquinas energéticas para a sociedade disciplinar. Deleuze sugere que as novas formas de exercício de poder provocarão saudades dos confinamentos mais severos.

O surgimento da sociedade de controle dá-se pela crise dos meios disciplinares, dos meios de confinamento. Apresenta-se como o novo monstro, mais plástico, mais fluido. O exame é substituído pelo controle contínuo, nunca se termina nada. A assinatura e o número de matrícula que indicam o indivíduo e sua posição na massa dão lugar a uma cifra, uma senha, que permite ou nega o acesso à informação. O produtor descontínuo de energia cede espaço ao homem ondulatório. A serpente destitui a toupeira.

Esta substituição de tecnologias revela-se no regime das prisões (penas substitutivas e "coleiras" de localização para o condenado), no regime das escolas (formação e avaliação contínua e abandono das pesquisas na Universidade), no regime dos hospitais (sem médico nem doente, doentes

${ }^{27}$ Controle e Devir e Post-Scriptum Sobre as Sociedades de Controle. In: Conversações, p. 209-226.

A \& C R. de Dir. Administrativo e Constitucional, Belo Horizonte, ano 4, n. 16, p. 11-28, abr.jun. 2004 
potenciais) e no regime das empresas (antes fábricas, menos necessidade de homens, mais valor ao dinheiro em espécie ou virtual). Estas modificações levam ao esvaziamento de espaços de luta, como os sindicatos que perdem seu referencial de resistência.

A mudança nas formas de poder relaciona-se com a mutação do capitalismo, que deixa de ser de produção e concentração (exigindo o confinamento) e passa a vender serviços e ações, dirigido à venda e ao mercado. O mercado e o marketing são a alma do controle social. A miséria provocada pelo capitalismo atingiu pessoas demais para o confinamento. O controle, permanente e ilimitado, transforma o seu objeto de poder: "O homem não é mais o homem confinado, mas o homem endividado". ${ }^{28} \mathrm{E}$ sem sentir que está sendo submetido - e assim menos capaz de resistir.

Michael Hardt e Toni Negri fazem uma análise da sociedade de controle pela visão do Império como forma paradigmática de biopoder. ${ }^{29} \mathrm{O}$ conceito de Império está centrado nas concepções de sociedade de controle e de biopoder.

O Império, lógica única, não tem um centro territorial de poder ("não tem Roma") e possibilita a união do poder econômico com o poder político, o projeto capitalista. Seu direito é atemporal, universalmente válido, eterno, permanente e necessário e origina-se de uma máquina biopolítica. Seu poder é descontínuo e reside no virtual.

A sociedade de controle revela-se com a "democratização" dos aparelhos de comando. O poder é exercido por máquinas que organizam os cérebros e os corpos e buscam a alienação dos indivíduos. A sociedade de controle corresponde, assim, a "uma intensificação e uma síntese dos aparelhos de normalização de disciplinariedade que animam internamente nossas práticas diárias e comuns, mas, em contraste com a disciplina, esse controle estende bem para fora os locais estruturados de instituições sociais mediante redes flexíveis e flutuantes" ${ }^{30}$

O biopoder submete à sua máquina todo o corpo social, e a sociedade reage a ele como um só corpo. Faz-se necessário quando o controle das subjetividades não pode mais ser realizado pelos poderes disciplinares. Constitui os poderes de produção e representa a ordem produtiva globalizada, a submissão da sociedade ao capital.

As lutas no Império são, ao mesmo tempo, econômicas, políticas e

\footnotetext{
${ }^{28}$ DELEUZE, Gilles. Post-Scriptum Sobre as Sociedades de Controle. In: Conversações, p. 224.

${ }^{29}$ HARDT, Michael; NEGRI, Antonio. Império.

${ }^{30}$ HARDT, Michael; NEGRI, Antonio. Império, p. 42-43.
}

A \& C R. de Dir. Administrativo e Constitucional, Belo Horizonte, ano 4, n. 16, p. 11-28, abr./jun. 2004 
sociais - lutas biopolíticas e constituintes, que não se comunicam porque não vislumbram um inimigo comum (o Império e a ordem disciplinar internacional), mas criam novos espaços públicos e novas formas de comunidade.

O Império, concentrando os poderes e os contrapoderes, acaba com o espaço público, com o lugar da política liberal moderna — há um déficit do político e em seu lugar está o espetáculo. O espetáculo da política, que destrói qualquer forma coletiva de sociedade, funciona como se houvesse um centro e uma vontade consciente e diretora de um único poder, e governa com o medo.

A resistência está no contra-Império, em uma tradição republicana radical de democracia moderna fundada na multidão.

Laymert Garcia dos $\operatorname{Santos}^{31}$ analisa a sociedade atual e a atuação da televisão e da Internet. A atual programação televisiva não serve para informar a massa dos espectadores, mas para expor e invadir a esfera privada. Há um controle pela aparência, fora dos limites impostos ao Estado de Direito.

Um outro problema levantado pelo autor é a utilização e difusão dos dados dos indivíduos. ${ }^{32}$ A integração dos bancos de dados constrói uma base de controle de comportamentos de maneira assustadora. Permite a leitura de individualidades à distância e o estabelecimento do perfil do indivíduo, e seu livre compartilhamento, antecipando desejos e necessidades.

O filme Minority Report, da 20th Century Fox e da Dreamworks Pictures, dirigido por Steven Spielberg e baseado em um conto de Philip K. Dick, mostra o cenário de uma sociedade de controle. ${ }^{33} \mathrm{O}$ filme passa-se em 2054, e há um programa da Polícia que prevê os assassinatos, através de visões.

\footnotetext{
${ }^{31}$ Limites e Rupturas na Esfera da Informação.

32 Isto é extremamente visível. Após formado em Direito, se não aparecer nas listas de aprovação do Exame da Ordem dos Advogados, você receberá inevitavelmente publicidade de cursos preparatórios, ainda que jamais tenha se dirigido a eles ou fornecido o seu endereço por qualquer meio ou mesmo tenha pensado em fazer o tal exame. Fazer comprar pela Internet também mostra o funcionamento desta técnica. Ao comprar por uma única vez ou apenas visitar um sítio de compras, as informações relativas às páginas que você visitou, os livros que the interessaram (ou que provocaram sua curiosidade), são armazenadas com o uso dos cookies e mostradas na sua próxima visita, antes mesmo de você se identificar formalmente. Alguns sítios solicitam a autorização para este procedimento, mas a maioria deles simplesmente o faz.

33 Uma análise do que poderia ser uma sociedade normalizada está no filme Gattaca, onde a elite pode manipular os genes de seus filhos e assim garantir-lhes um futuro melhor. O acesso a determinadas profissões e atividades é permitido apenas àqueles que possuem o perfil genético adequado. Os demais, geneticamente excluídos, dedicam-se a atividades subalternas. A resistência consiste na compra de material genético (fios de cabelo, por exemplo) de "perfeitos" que se revoltaram com seu destino já traçado e ficam à margem da sociedade.
} 
Há uma espécie de oráculo, formado por três pessoas (pre-cogs, filtros de reconhecimento de padrão), filhos de drogados que têm o dom da premonição. Os policiais de uma divisão pré-crime analisam a visão e através de um rápido trabalho de investigação descobre onde será o assassinato. "Testemunhas" (uma doutora e um juiz) confirmam o futuro crime. O crime é impedido e o indivíduo que iria cometê-lo é preso pelo assassinato futuro.

São colocados arcos nos prisioneiros, que os fazem entrar em um estágio letárgico, e a "prisão" é formada por cápsulas. Junto a cada prisioneiro há um arquivo do assassinato que seria cometido, do criminoso em potencial e até da vítima, com sua situação atual. Há apenas uma sentinela para milhares de indivíduos presos.

Para a investigação, os policiais acessam bancos de dados amplos e interligados, onde são possíveis a comparação de registros e a análise simultânea de fragmentos de informações. Além dos dados registrados, há identificadores de retina em todos os lugares (metrôs, edifícios, outdoors) que mapeiam a localização e o comportamento dos indivíduos. A identificação pela retina permite e proíbe o acesso e mantém um rastreamento absoluto.

Ao andar pelas ruas, os identificadores de retina nos outdoors fazem publicidade diretamente para o indivíduo, chamando-o pelo nome e expondo os produtos de seu interesse, adequado ao seu perfil de consumo. Em lojas o sistema também é utilizado, com referência a compras anteriores. Há espaços de realidade virtual onde se compram sensações.

A "resistência” ao sistema dá-se com a troca de olhos para enganar os identificadores. Há drogas para quem busca "lucidez".

O filme traz referências nada absurdas. A identificação do perfil de consumo já é largamente feita, e o compartilhamento dos bancos de dados é uma realidade. A sociedade de controle está aí.

Frente a este poder que tudo vê, o cidadão está totalmente vulnerável. Não há legislação que o proteja nem instâncias que o defendam. Aliás, por vezes o indivíduo sequer é consciente desta vigilância. Aqui não há liberdade possível — outro espaço de luta que se impõe.

\section{Conclusão: a busca de novas armas}

Na sociedade de controle a dominação é difusa pela sociedade. Nela se combinam o poder soberano, o poder disciplinar, o biopoder e o controle. O poder está em todos os lugares, sujeitando o indivíduo.

A \& C R. de Dir. Administrativo e Constitucional, Belo Horizonte, ano 4, n. 16, p. 11-28, abr./jun. 2004 
No totalitarismo o Estado está em todos os lugares, mas é um poder visível, tem um centro, algo que pode ser atacado. A formação da resistência e a busca por liberdade têm seu espaço definido.

Na sociedade de controle os poderes não são percebidos, não são visíveis. É um poder disseminado, oculto, espalhado entre pequenos déspotas, grandes corporações e computadores. É um poder sem centro, sem cara.

Falar de sociedade democrática hoje somente é possível com relação ao poder soberano. Os direitos fundamentais, constitucionalizados e garantidos, limitam o poder do Estado, impõe o princípio da soberania popular, a liberdade e a igualdade. Ainda que esta democracia não encontre pleno eco na realidade, as ferramentas para a sua conquista já estão postas.

A luta pela democratização das relações sociais, proposta por Gramsci e por Mouffe, é mais difícil. Os meios de luta ainda não estão claramente colocados. Embora se possa considerar a guerra de posição como uma estratégia democrática, a difusão em micropoderes dificulta a organização da resistência. Quanto a estes, é necessário antes de tudo denunciar, tornálos evidentes.

Com a virada de Foucault, e o desvelamento do poder disciplinar e do biopoder, a denúncia já está feita. Não é possível negar a sujeição dos indivíduos frente a estes poderes. As armas e a resistência frente ao poder disciplinar passam pelo cuidado de si, trabalhado por Foucault, mas isto exige uma conscientização profunda do indivíduo. Esta emancipação não consegue levar junto a massa de pessoas. Cada um deve fazer isto sozinho.

Contra o biopoder, a estratégia de resistência não parece evidente. Talvez somente a tribalização da sociedade pode fazer com que se escape dele. Ou a invenção de novas formas democráticas pela multidão, conforme assinala Toni Negri.

E o controle dos computadores e das teias de dados, como poderá ser combatido? Este poder incorpora os demais e distrai seus sujeitados com o espetáculo. Vigia todos em todos os momentos e ainda encontra quem queira se expor declaradamente. Estamos nus diante dos olhos de todos, pois o panótico se amplia e se mostra simultaneamente invertido. É o panótico misturado à sociedade do espetáculo.

As armas para combater a sociedade de controle e sua resistência passam pelos piratas e pela proliferação de vírus pelos computadores. Mas devem ir além disso. Devem buscar escancarar o exercício deste conjunto de

A \& C R. de Dir. Administrativo e Constitucional, Belo Horizonte, ano 4, n. 16, p. 11-28, abr./jun. 2004 
poderes e fazer com que o sujeito tome consciência da sua existência. A partir daí cada indivíduo pode pensar estratégias para escapar do rastreamento.

Além da libertação pessoal, a luta deve incorporar ações sociais, de coletividades unidas por qualquer interesse (pois há equiparação das lutas democráticas), desde que coerentes com a idéia de democracia.

A luta pela liberdade e pela igualdade - fundamentos da democracia — não se esgota no Estado. A ameaça ao indivíduo não vem do poder soberano. A ameaça é disseminada, invisível e devastadora. $\mathrm{O}$ inimigo não mostra a sua cara, não há estratégia construída. Mas a batalha deve ser travada, se for real o desejo de uma sociedade democrática.

Nesta frente, com Deleuze, não cabe temer ou esperar, mas buscar novas armas

\section{Referências}

A \& C R. de Dir. Administrativo e Constitucional, Belo Horizonte, ano 4, n. 16, p. 11-28, abr.jun. 2004 